\title{
Chapter 4 \\ Broad and Coarse: Modelling \\ Demography, Subsistence and Transportation in Roman England
}

\author{
Tyler Franconi and Chris Green
}

\begin{abstract}
The English Landscape and Identities project (EngLaId), which ran from 2011 to 2016 (ERC grant number 269797), was designed to take a long-term perspective on English archaeology from the Middle Bronze Age (c. 1500 BCE) to the Domesday survey (1086 CE). It was a legacy data project that collated an immense number of records of English archaeology from a large number of different public and academic sources. Within this mountain of material, the Roman period (43 to $410 / 411 \mathrm{CE}$ ) stood out as being particularly fecund, accounting for $40 \%$ of the data (by record count) coming from only $15 \%$ of the total timespan of the project. This paper examines the ways in which the EngLaId project approached the modelling and analysis of its data for Roman England. We focus here on the three themes of demography, subsistence economy and transportation. Overall, EngLaId provides an interesting contrast to the possibilities and limitations of the other projects presented in this volume because of its large spatiotemporal scale and its (thus necessary) broad-brush approaches to data analysis and modelling. It is also this large spatiotemporal scale that helps situate the Roman period within a much longer span of history, making evident what was unique to this time period and what was constant across multiple periods.
\end{abstract}

Keywords England · Roman · Landscape archaeology $\cdot$ Big data · GIS

\footnotetext{
T. Franconi $(\bowtie)$

Department of History and Classics, University of Alberta, Edmonton, AB, Canada

e-mail: franconi@ualberta.ca

C. Green

School of Archaeology, University of Oxford, Oxford, UK

e-mail: christopher.green@arch.ox.ac.uk
} 


\subsection{Introduction}

The English Landscapes and Identities project (EngLaId) ran from 2011 until 2016 and was funded by the European Research Council. It was in essence a legacy data project that collected a very large amount of material on the archaeology of England covering the timespan from the Middle Bronze Age (c. 1500 BCE) to the Domesday survey of $1086 \mathrm{CE}$. The team gathered a database of over 900,000 records of archaeological sites (including find-spots and also uncertainly dated material) from a large number of sources. These included almost all of the local government/national park-based Historic Environment Records (HERs), Historic England (HE), the Portable Antiquities Scheme (PAS) and a number of other smaller datasets collated by individuals or other bodies. The team also gathered various ancillary datasets including the results of HE's National Mapping Programme, the grey literature library held by the Archaeology Data Service (ADS), and HE's Index of Excavations (also curated by the ADS). This mass of material was complex and rich in detail but was mostly rather high level: in other words, the data could describe English archaeology at the scale of sites and landscapes but could answer few questions on an intra-site or contextual basis, simply due to lack of consistent recording of archaeology at greater levels of detail than the site. All told, the archaeological records contained in the EngLaId database cover a range of site types that were simplified down to 119 defined types and grouped into 8 categories: agriculture and subsistence; religious, ritual and funerary; domestic and civil settlements; architectural forms; industry; communication and transportation; defensive structures; and a final catchall for 'other' (Green et al. 2017, 246-247; https://englaid.arch.ox.ac.uk/). In addition, find types ranging from coins to weapons were also included, but these are not relevant to the discussion herein.

As such, the datasets gathered by the project could be best put to use in the exploration of questions and themes at a rather broad-brush scale/resolution. Although more detailed case studies were undertaken, at a national level there was little possibility for manual cleaning of our data, and so the data was resampled using spatial bins (see Green 2013 for more detail) to minimize problems caused by imprecise spatial coordinates and double (or more) counting of the same objects across multiple datasets (see Cooper and Green 2016). The national-level models presented here have thus passed through a stage of being binned into 1-by-1-kilometre cells before any analysis was undertaken, with the presence/absence of each type of site defined (e.g. 'cremation cemetery', 'villa', 'hillfort', etc.) recorded for each cell. Although this process will have removed some level of detail on a high-resolution spatial scale, this should not have unduly affected models created at low-resolution spatial scales, such as investigations carried out at the national level.

Obviously, England is not an entity that existed until perhaps the very end of our time period of interest and certainly did not exist during the Roman period that is the focus of this particular paper. However, one must set limits to any analysis and using the bounds of modern-day England allowed a reasonable degree of consistency to exist across most of the original data sources gathered, as almost all of the bodies 
from whom we collected data are governed by guidelines set by HE (the HERs and $\mathrm{HE}$ itself at least). If we had included data from Wales or Scotland, or from Ireland or the near continent, then that would have increased the time taken both to gather and to rationalize the data, which was already not insignificant. As such, although 'England' remains an anachronous construct for the majority of our time period, it is a convenient construct nevertheless.

Throughout the approximately 2500-year time period covered by the EngLaId project, the approximately 400 years of the Roman period stands out as particularly significant in terms of the amount of data. Around $40 \%$ of the records in our main database are of Roman date, despite the period only representing around $15 \%$ of the Bronze Age to early medieval time period as a whole. Demonstrably, the RomanoBritish left a lot more evidence of their existence in (and above) the ground for archaeologists (and others) to discover than their prehistoric predecessors or (early) medieval successors did. This could be explained in a number of ways: there may have been more people (the demographic explanation), there may have been more intensive exploitation of resources (the subsistence economy explanation) or there may have been stronger links between different places both within and outside England (the transportation explanation). Almost certainly, the answer will be a mixture of these explanations and others (including the modern factors that partially structure the recovered archaeological record, as discussed in Green et al. 2017, 253-256; Cooper and Green 2016), but these three themes will be the subject of the rest of this paper, also aligning well as they do with the topics of the other papers presented in this volume.

\subsection{Demography}

The massive amount of data from the Roman period led us to first re-examine an age-old archaeological question: how does the distribution of sites and artefacts relate to the numbers of people that left them behind? The demography of the Roman Empire has recently been the subject of a number of studies that range from regional (Marzano 2011; Hanson 2011) to Empire-wide studies (Scheidel 2007; Wilson 2011; Hanson 2016). These studies have generally relied on estimates of urban populations based on hypothetical settlement densities within defined city spaces that are then extrapolated to estimate the (much larger) rural population. Exact methodologies and outcomes vary widely, from low estimates of 54 million (Beloch 1886, 501-507) to high estimates of 122 million (Hanson 2016, 72) in the middle of the second century CE. Within this Empire-wide uncertainty, regional estimates of provincial populations reflect the same orders of variation. For the province of Britannia, estimates range from 2 to 2.5 million (Frere 1987, 311; Jones 2004; Mattingly 2006) to as high as 5-6 million (Salway 1981, 544). There is, therefore, much said about Roman demography, but very little proven. Outside of pure numbers, there are significant obstacles in understanding both geographical and 
chronological fluctuations in demographics as well, as the situation of the early Roman Empire would undoubtedly be very different from that of 200 or $400 \mathrm{CE}$.

Because of these difficulties and others, the EngLaId team did not attempt to model actual population numbers within its study region, as it seemed unlikely that any accurate measures could be derived from the data to hand, especially considering the amount of work already done inconclusively on the subject. Instead, we sought out proxies that ought to relate on some level to relative population density in the past. After some experimentation, we settled on a rough proxy based upon the complexity of information for each time period in each 1 by 1 kilometre cell, averaged out across space using Kernel Density Estimate (KDE) modelling (see O'Sullivan and Unwin 2010, 68-71). The complexity measure was essentially the number of different types of site within each cell based upon the terms defined in our site type simplification thesaurus (which contained 119 different potential
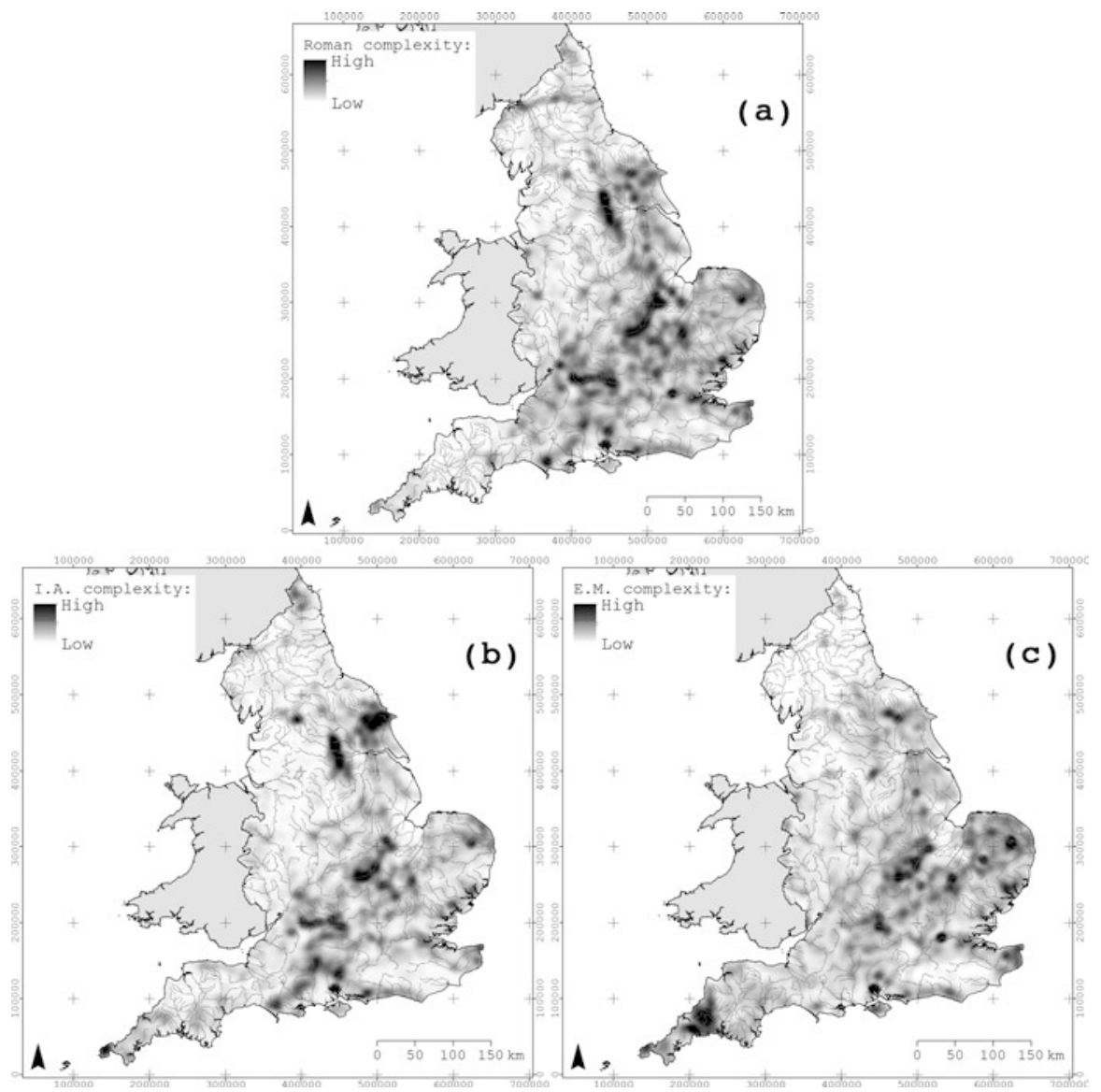

Fig. 4.1 Models of relative complexity of archaeology for the (a) Roman, (b) Iron Age, and (c) early medieval periods 
types). The methodology has been explained and its merits/problems have been discussed in detail elsewhere (Green et al. 2017), but essentially we argue that these models must relate on some level to variation in population density across England, as more people ought to mean more archaeological remains and more variety of archaeological remains, at least if we are dealing with relatively settled lifeways. The models were normalized for cross comparison using $z$-scores (i.e. subtracting the mean and dividing by the standard deviation).

The model of relative data complexity for the Roman period (Fig. 4.1a) shows a large and partially discontinuous peak that covers most of south eastern England, with some smaller peaks in the north and west which are mostly associated with military landscapes (e.g. Hadrian's Wall). Particular peaks within the zone of higher general complexity include the Thames and Nene river valleys and a swathe of countryside to the south and west of the legionary fortress and colony of York. The area of the Weald of Kent and Sussex shows a clearly lower density, as an area known mostly for iron working in the Roman period and which is generally of low complexity throughout the total time period studied by the EngLaId project. When compared against the preceding Iron Age (Fig. 4.1b) and succeeding early medieval periods (Fig. 4.1c), the earlier period shows a similar overall pattern but with a more restricted zone of higher complexity, alongside a notable peak in North Yorkshire that is reduced in the Roman period. The later period shows a generally lower value but also generally similar overall pattern, albeit with a much stronger peak of high complexity in the Cornwall/Devon peninsular. East Anglia also shows a much broader peak of high complexity, which is of little surprise as this region is traditionally characterized as one of the heartlands of Anglo-Saxon migratory settlement.

Although clearly not direct models of variation in past population density, the results presented here do suggest that the south eastern half of England must have seen relatively greater densities of settled (i.e. archaeologically visible) peoples throughout the Iron Age to early medieval periods. It is unfortunate that the coarseness of dating evidence for the majority of our data does not allow modelling at finer temporal resolutions, as it seems inevitable that the patterns presented must also have varied within each time period, whether due to changing economic circumstances, migration or plague (among other factors). Nevertheless, we would hope that these relatively simple models will help provide background context for more detailed work on the past demography of Roman Britain in the future, especially in comparison to earlier and later periods.

\subsection{Subsistence Economy and Landscape Change}

These regionally and chronologically varied patterns of settlement across Roman England had similarly varied impacts on the landscape, especially through agricultural exploitation. The EngLaId project was broadly interested in the relationship between society and environment through all periods, investigating how human 
development resulted in environmental change and, conversely, how environmental dynamism caused societal change, and agricultural exploitation of the English landscape formed a central area of investigation. England, especially the southeast, had been at least partially cleared since the Neolithic period and farmed in a settled way since at least the middle Bronze Age, and thus significant portions of the territory were already ancient farmland by the time of the Roman invasion (Fyfe et al. 2013; Edwards et al. 2015). The Roman period saw similar spatial patterns of exploitation in the southeast, and they increased the amount of land under cultivation in wetlands (Rippon 2007; Van de Noort 2011) as well as in the north and west (more on this expansion below). Some regions show remarkable continuity into the early medieval period, especially in the southeast (Rippon et al. 2015), as farmers in this period continued to exploit Roman-era field systems.

The agricultural exploitation of the English landscape through time left noticeable markers in environmental archives, including pollen (Dark 2006; Fyfe et al. 2013; Edwards et al. 2015) and fluvial sequences (Brown 1997; Macklin et al. 2014). Both of these datasets suggest significant environmental change through time, often corresponding to shifts in human activity, such as new technologies (e.g. the introduction of the ard plough c. $1500 \mathrm{BCE}$ ) or new settlement patterns (e.g. the establishment of a permanent garrison along the Hadrian's Wall corridor c. 122 CE). The Roman period left its mark in these environmental records in different ways, but fluvial sequences show a repeated pattern of rivers entering into periods of hydrological crises during the later first and second centuries $\mathrm{CE}$. These crisis periods are marked by an increase in floods and alluviation and, in some cases, by an accompanying rise in groundwater level. While climatic change could have played some role in these hydrological processes (see Franconi 2017a for an overview of this relationship), the chronology of fluvial change in Britain seems to predate the onset of significantly different patterns in temperature or precipitation fluctuation, indicating a different, anthropogenic driver.

While the Roman Empire did not necessarily introduce new agricultural methods to Britain (both arable agriculture and animal husbandry already had a long history by $43 \mathrm{CE}$ ), it certainly introduced a new scale of exploitation, visible in the increased extent of field systems and rural settlement (Smith et al. 2016; Allen et al. 2017). The necessity for farmers to produce income to pay taxes to the Roman State, either through cash or products in kind, helped drive an agricultural revolution that saw an increase in both the amount of land under cultivation and the intensity with which this land was worked. The fiscal necessity was augmented by substantial growth in both urban and military populations throughout the new province, increasing the need for farmers to produce a surplus that could be sold on to non-agricultural populations. Thus, while significant amounts of the English landscape were already given over to agriculture at the end of the Iron Age, the Romans dramatically increased the demands on the landscape. This legacy is perhaps most archaeologically visible in the creation of villa landscapes.

This increased demand on agricultural land came with an environmental price. By clearing more land for agriculture (as well as for timber for construction and fuel), and by continuing to plough existing fields year after year, the Roman 
agricultural economy increased surface erosion of soils across the country. As soils were exposed and loosened by Roman farming, they were washed away by rainfall, travelling via surface flow into river systems where the sediment was then carried downstream to floodplains where it was subsequently re-deposited as alluvium during floods. It is this alluvium that we find preserved on archaeological sites today, and its frequency of appearance during the middle- and late-Roman periods on riverside sites certainly suggests an increasingly changed hydrological system.

Sites with these sorts of environmental archives are relatively well known in Britain, especially within the Thames River basin (Robinson and Lambrick 1984; Robinson 1992; Booth et al. 2007; Lambrick et al. 2009; Powell et al. 2010). These site-based chronologies give solid evidence of hydrological change, but their anecdotal nature requires a model-based approach to extrapolate their societal context to larger scales.

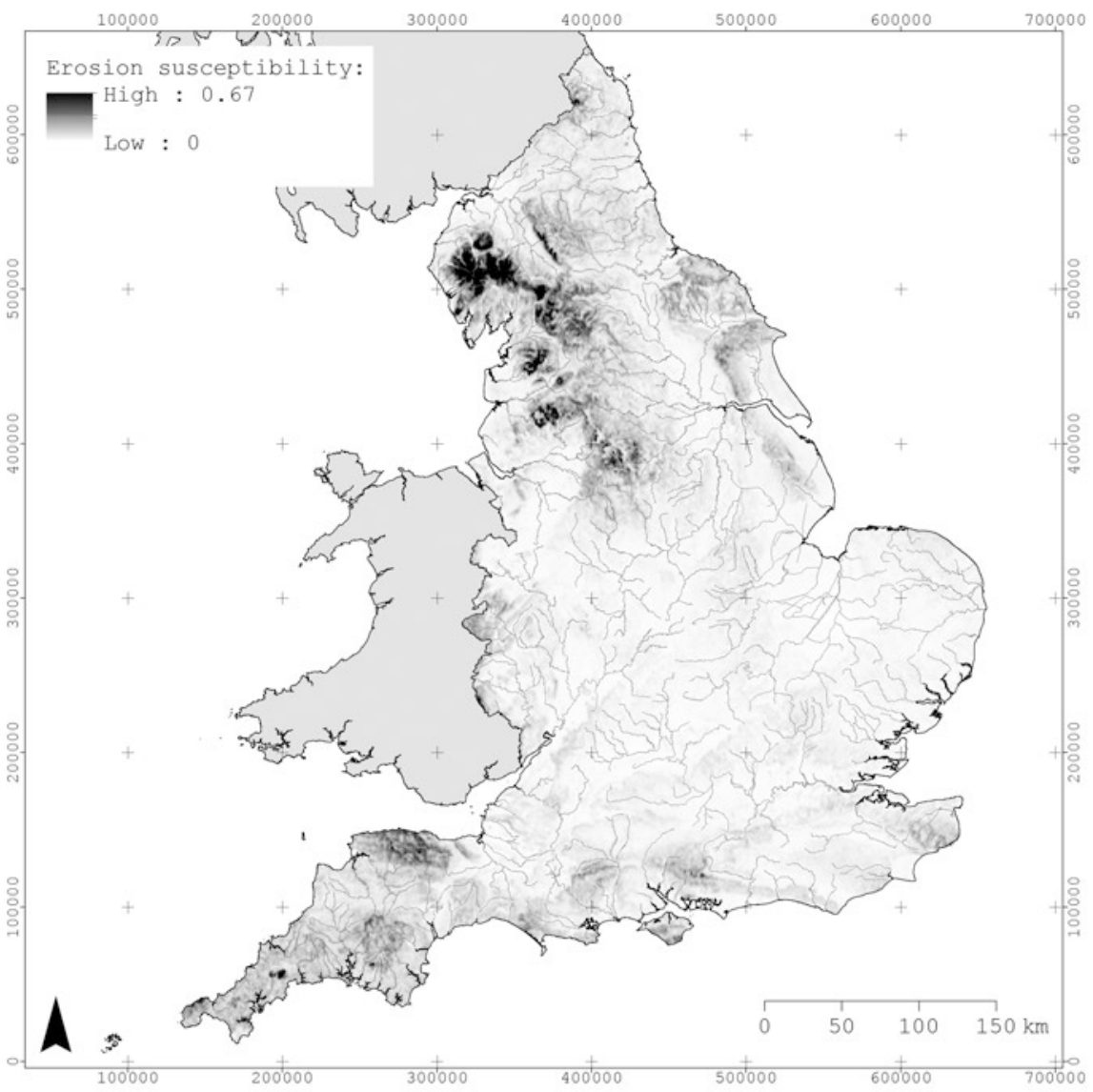

Fig. 4.2 Erosion susceptibility in England 
The EngLaId project thus created a model of soil erosion susceptibility for England, based on a variety of pedological, climatic and topographic qualities, such as soil erodibility, slope angle and length, rainfall erosivity and wind erosivity that were compiled by the European Soil Data Centre and made available online (https:// esdac.jrc.ec.europa.eu/). These raster data were combined using GIS and normalized, resulting in a range of values from 0 to 1 , and then subjected to kriging to interpolate between the known values (O'Sullivan and Unwin 2010, 293-311). The resulting model of erosion susceptibility (Fig. 4.2) shows significant regional variation, with the Thames Basin actually showing relatively low susceptibility while regions like the Pennines and the Lake District Fells in the northwest, the Yorkshire Dales and Cheviots in the northeast, and Dartmoor, Exmoor and Cornwall in the southwest show much higher levels of erosion susceptibility.

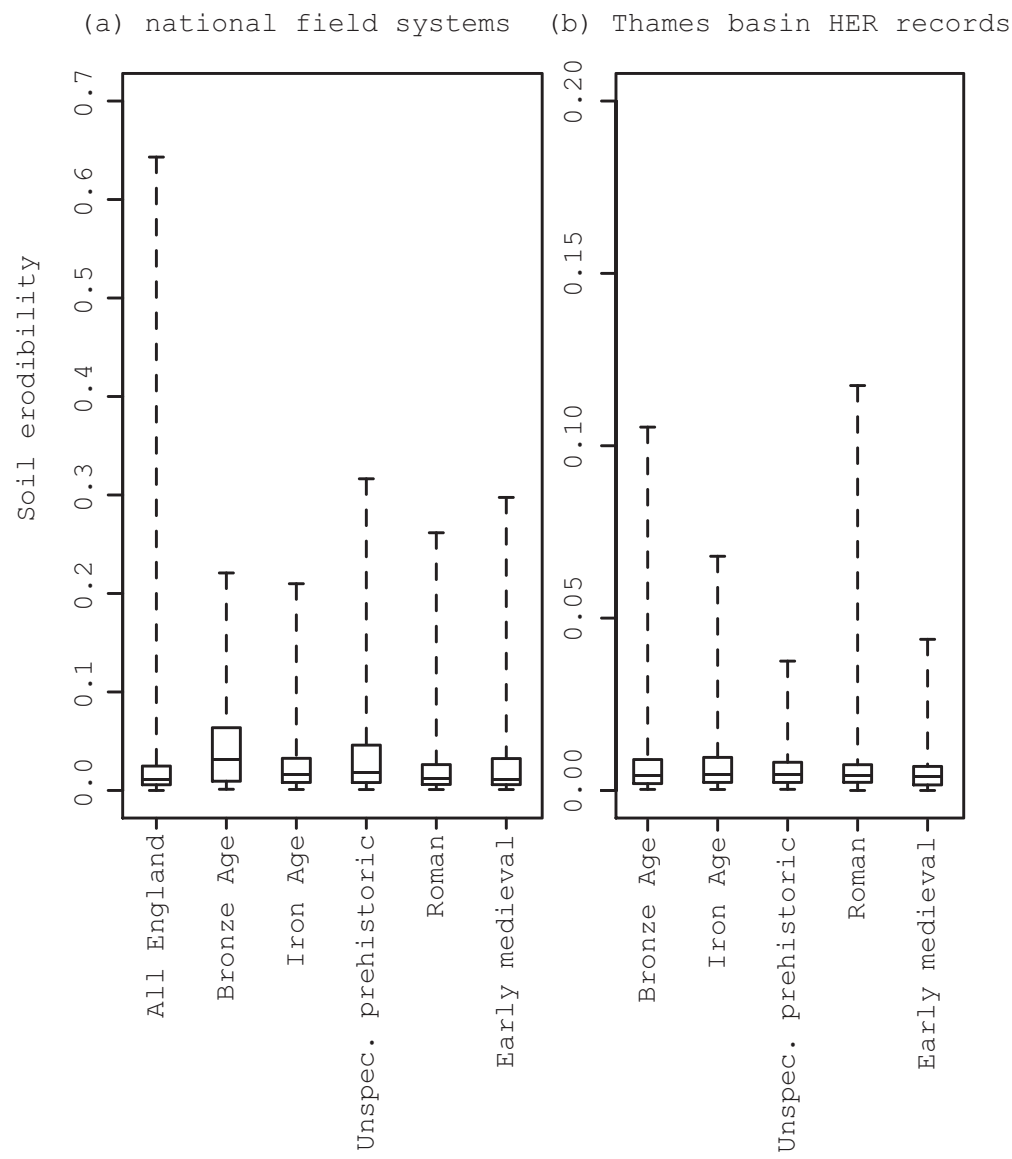

Fig. 4.3 Erosion susceptibility of (a) field systems by period at national level and (b) all records in the Thames Basin 
Using this model, we were able to extract the erosive values of field systems throughout all EngLaId periods and gauge the relative impact of Bronze Age, Iron Age, Roman and early medieval agriculture on erosive activity nationwide. The resulting boxplots (Fig. 4.3a) by period did not show a significantly varied temporal pattern in the overall range of soil erodibility, and this can be explained by the relative homogeneity of a low erosive susceptibility across most flat, low-lying agricultural land in the south and east of the country: the exception to this is the Bronze Age, where upland field systems do show greater levels of potential soil erosion. We recognized, however, that this nationwide pattern obscured significant local variation, and so a second step of analysis was performed at the scale of river catchment basins.

The Thames Basin was chosen as a detailed case study, in part to look at the systemic patterns that helped create the archaeologically visible pattern of hydrological change discussed above. Within the Thames Basin (Fig. 4.3b) and looking only at HER records to avoid issues regarding overlapping datasets, we see a decrease in activity on more erosive land from the Bronze Age to the Iron Age, followed by an increase again in the Roman period, albeit with the majority of activity in less erosive areas according to the model. This change can be explained through an increase in Roman activity on slopes, especially the Berkshire Downs, Chilterns and North Downs, each part of the chalk ridgeways that crosses the basin on a southwest-northeast orientation. The higher susceptibility of erosion on these slopes meant that more sediment entered the Thames Basin during this time, leading to the increased deposition of alluvium on the floodplains of the river in the second and third centuries. Medieval activity closely followed this same spatial pattern, but we do not see similar peaks in hydrological crisis periods at this time. We can perhaps attribute this return to environmental normalcy to the removal of state impetus to produce a massive surplus, which ended with the removal of Roman fiscal control in the early fifth century CE (Rippon et al. 2015, 337-338), lessening the intensity with which the landscapes of the Thames Basin were worked.

We can see, therefore, that the Roman period in England had a relatively brief, but nonetheless substantial, impact on the environment of the province of Britannia. This pattern of increased strain on the landscape is seen elsewhere in the Roman Empire (Franconi 2017a, b), but has yet to be explored at the system level made possible by the extensive archaeological data compiled by the EngLaId project. The resulting national and regional models discussed here are, then, a step towards understanding the ways in which the Roman Empire exercised a significant influence over its environment.

\subsection{Transportation}

The increasingly developed and connected landscape of Roman England required a commensurate level of infrastructural development that could link rural settlement, towns, cities and military sites together into a system of easy communication and 
exchange. The rapid development of this system in the first century CE has been referred to as Britain's ‘first information revolution' (Haynes 2000, 112-113) that mainly centred on the creation of the provincial road network (Margary 1973) but also important river and sea hubs that helped link Britannia to the rest of the Empire (Blair 2007; Morris 2010).

The EngLaId team was interested in the long-term development of connections both within England and without, as we wished to know how movement, transportation and communication changed through time. It was clear, however, that the Roman period saw such a dramatic increase in route ways and connective hubs that the earlier periods were dwarfed in comparison. The differences in scale between the Bronze and Iron ages and the Roman and early Medieval periods were so striking that it became clear that in order to understand the relative contributions of each period, a different approach was needed rather than just counting roads or something similar.

As with demography, the EngLaId team built a series of proxy models for potential transportation cost rather than attempting to model movement in a more formalized manner. As with population, density of archaeological data was used as a proxy for how connected people living in different regions of England were in the past, on the assumption that greater connectivity implies greater access to goods and to economic enrichment, and that travel costs ought to be lower in areas of dense, wellconnected settlement. In these models, the density measures were converted into cost allocation surfaces and used to produce a series of cost surfaces (see Herzog 2014 for detailed discussion of cost modelling) from a large number of points. These were then summed together to build a combined model of cumulative cost across the country, and normalized (to remove edge effects) by dividing by a similar cumulative cost model constructed using a cost allocation surface of constant cost: if this were not done then the only visible pattern would be a radiating zone of increasing cost out from the low cost centre of England. Again, the models were normalized for cross comparison using $z$-scores (see above).

It is very clear that the model of travel cost for the Roman period (Fig. 4.4a) shows notably lower costs in the areas of higher complexity seen in the demographic proxy model for the same period (Fig. 4.1a). As the two models are derived from the same dataset and the transport model based upon an assumption of 'more people equals lower cost', clearly this should be expected. The appearance of clear road lines within the travel model is a pleasing result, alongside routes that appear to travel along river valleys in some regions. As Roman roads were part of the dataset used to create the model, again this is somewhat expected. When compared against the preceding Iron Age (Fig. 4.4c) and succeeding early medieval periods (Fig. 4.4d), however, the continuing appearance of some of the road lines (particularly in the later period) is of particular note as the Roman roads were not themselves built into these datasets (due to being dated to the Roman period). Of particular importance appears to be the communication corridor that runs north through the eastern central part of England, as this appears as a clear route of low cost in all three models. This is approximately equivalent to the modern A1 road, 


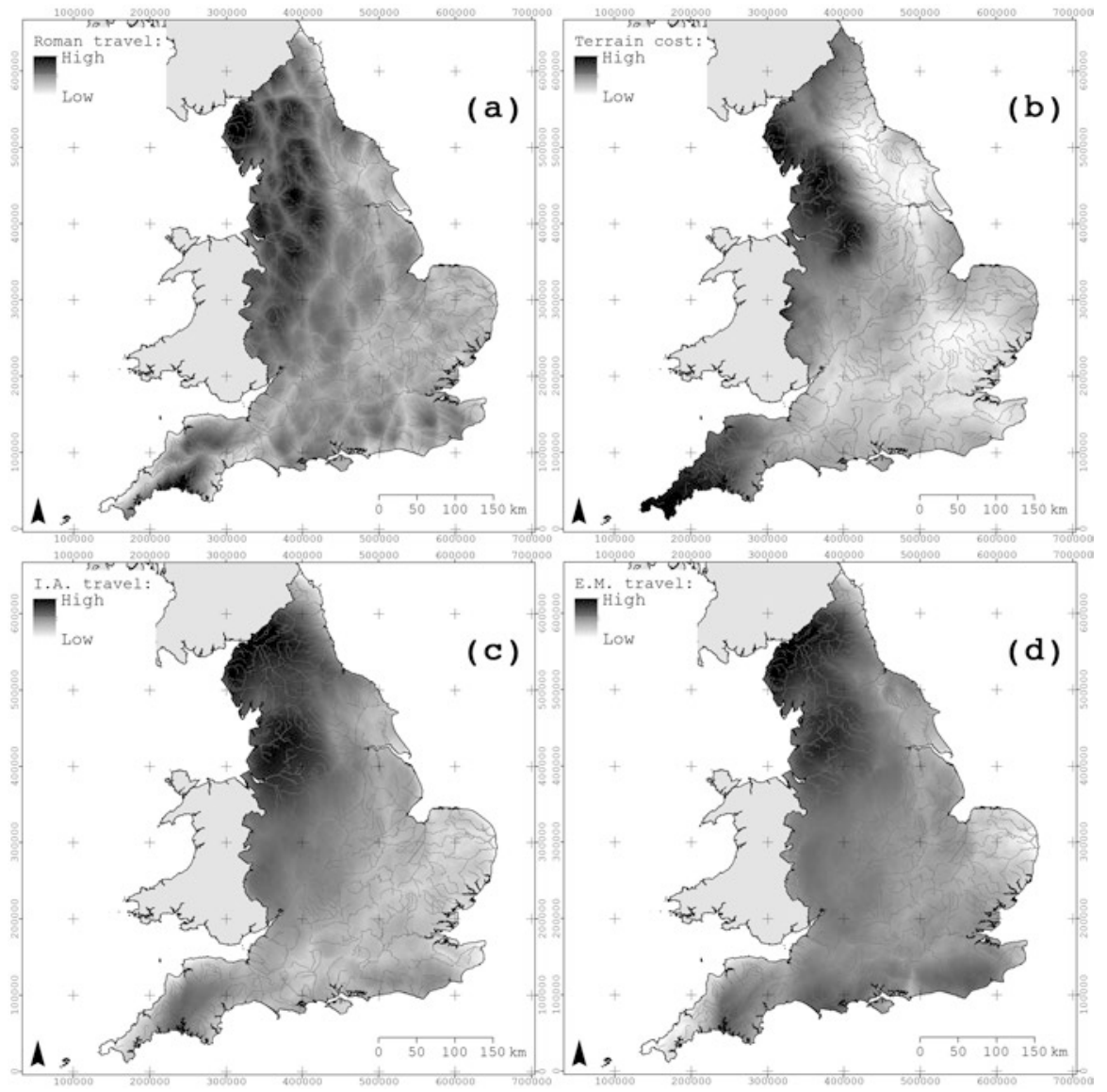

Fig. 4.4 Model of relative transportation cost (proxy) for the (a) Roman, (c) Iron Age, (d) early medieval periods, and (b) based on terrain character

which, as its numeric designation suggests, is one of the most important nonmotorway arterial transport routes in modern day England.

A somewhat more conventional transportation cost model was also constructed for England using the same cumulative cost surface method (Fig. 4.4b). This was based upon terrain ruggedness (double-weighted to give it prime importance), a model of terrain wetness (based upon flow accumulation, modern wet and seasonally wet soils and modern precipitation) and a model of visual prominence of the landscape (on the assumption that travel through visually prominent locations would be desirable for people travelling on non-nefarious business). This combined transport cost model shows a very clear divide between the rugged and wet western half of England (where most rainfall falls due to the elevated ground causing weather systems travelling inland from the Atlantic to deposit their moisture as precipitation) showing much higher relative travel costs that the drier and less rugged (albeit 
less visually open due to lack of elevated areas) landscape of the eastern half of England. Of particular note is the broad concordance of this model with the models presented above using purely archaeological data. This is again particularly notable for the communication corridor running north through eastern central England, but also for the area represented approximately by the modern counties of Northamptonshire and Cambridgeshire. The way in which these models derived from different datasets all generally support one another suggests that these may form relatively strong proxies for the degree of transport connectivity present in Roman period England.

As with the demographic models, these transportation models are also clearly rather rough proxies for how movement of people and goods might have taken place in the past, and finer chronological resolution would also undoubtedly pick out further subtle change over time. However, it is apparent that again the southeastern half of England was more interconnected and communicative than the other half of the country throughout time, with major routeways clearly having their origins in the pre-Roman period and clearly surviving in part into the early medieval period (indeed, as many so-called Roman roads still survive in the transport network today). As with the demographic models, we would also hope that these transportation models provide context and inspiration for further study of transport and communication (and trade) in Roman Britain.

\subsection{Conclusions}

The EngLaId project was not designed with a specifically Roman-centred research agenda, but it was clear that no matter what question was asked of the longue durée of English history, the Roman period had a significant contribution to its archaeological appearance. The case studies of demography, the environmental impact of agriculture and the transportation infrastructure were three of the main foci of the project's investigation of Roman England, though there were others in resource management, ritual activity, systems of enclosure, literacy and material consumption that cannot be discussed in the space available here. The examples of demography, agriculture and transportation show that the Roman period was a substantially different beast in the long-term history of the English landscape. The years between the conquest of $43 \mathrm{CE}$ and the provincial abandonment of 410/411 CE left a remarkable and lasting imprint on England that was both distinct from what came before and prescriptive of what would come later. Future scholarly narratives of change and continuity in Britain must be written with an awareness of the scale of these changes that are visible at the macro level.

These case studies also help demonstrate the incredible value of being able to interrogate national datasets of Roman archaeology. While other countries in Europe may have similarly strong datasets (see Bradley et al. 2015 for an overview of the prehistoric data on both sides of the English Channel or Demján and Dreslerová 2016 on Bohemia), few have been able to be brought to bear on major questions in 
Roman archaeology, and thus the EngLaId project offers a particular insight into the problems and possibilities that lay ahead in the creation of a more complete (national or international) dataset of Roman archaeology, and the types of questions that can or cannot be addressed at these scales. The future of the discipline lies in being able to marshal increasingly large and international datasets to address important historical issues, and we hope that the EngLaId project will help focus these research agendas as they develop.

Acknowledgements The English Landscape and Identities project (EngLaId), which ran from 2011 to 2016, was funded by the European Research Council (Grant number 269797). We would like to thank them alongside all of the various people and organizations who provided us with data and also alongside our colleagues for providing a rich and rewarding research environment. At the time of writing, a simplified version of the EngLaId dataset can be explored at https://englaid.arch. ox.ac.uk.

\section{References}

Allen M, Lodwick L, Brindle T, Fulford M, Smith A (2017) The rural economy of Roman Britain: new visions of the countryside of Roman Britain, vol 2. Society for the Promotion of Roman Studies, London

Beloch KJ (1886) Die Bevölkerung der griechisch-römischen Welt. Duncker \& Humbolt, Leipzig

Blair J (ed) (2007) Waterways and canal-building in medieval England. Oxford University Press, Oxford

Booth P, Dodd A, Robinson M, Smith A (2007) The Thames through time: the archaeology of the gravel terraces of the upper and middle Thames: the early historical period, AD 1-1000. Oxford Archaeology, Oxford

Bradley R, Haselgrove C, Vander Linden M, Webley L (2015) The later prehistory of north-West Europe: the evidence of development-led fieldwork. Oxford University Press, Oxford

Brown AG (1997) Alluvial geoarchaeology: floodplain archaeology and environmental change. Cambridge University Press, Cambridge. https://doi.org/10.1017/CBO9780511607820

Cooper A, Green C (2016) Embracing the complexities of 'big data' in archaeology: the case of the English Landscape and Identities project. J Archaeol Method Theory 23:271-304. https:// doi.org/10.1007/s10816-015-9240-4

Demján P, Dreslerová D (2016) Modelling distribution of archaeological settlement evidence based on heterogeneous spatial and temporal data. J Archaeol Sci 69:100-109. https://doi. org/10.1016/j.jas.2016.04.003

Dark P (2006) Climate deterioration and land-use change in the first millennium BC: perspectives from the British palynological record. J Archaeol Sci 33:1381-1395. https://doi.org/10.1016/j. jas.2006.01.009

Edwards KJ, Fyfe RM, Hunt CO, Schofield JE (2015) Moving forwards? Palynology and the human dimension. J Archaeol Sci 56:117-132. https://doi.org/10.1016/j.jas.2015.02.010

Franconi TV (2017a) Studying rivers in the Roman world. In: Franconi TV (ed) Fluvial landscapes in the Roman world. Journal of Roman Archaeology, Portsmouth, RI, pp 7-22

Franconi TV (2017b) Pater Rhenus: the hydrological history of Rome's German frontier. In: Franconi TV (ed) Fluvial landscapes in the Roman world. Journal of Roman Archaeology, Portsmouth, RI, pp 85-96 
Frere SS (1987) Britannia: a history of Roman Britain. 2nd Edition. Routledge and Kegan Paul, London

Fyfe RM, Twiddle C, Sugita S, Gaillard M-J, Barratt P, Caseldine CJ, Dodson J, Edwards KJ, Farrell M, Froyd C, Grant MJ, Huckerby E, Innes JB, Shaw H, Waller M (2013) The Holocene vegetation cover of Britain and Ireland: overcoming problems of scale and discerning patterns of openness. Quat Sci Rev 73:132-148. https://doi.org/10.1016/j.quascirev.2013.05.014

Green C (2013) Archaeology in broad strokes: collating data for England from 1500 BC to AD 1086. In: Chrysanthi A, Wheatley D, Romanowska I, Papadopoulos C, Murrieta-Flores P, Sly T, Earl G (eds) Archaeology in the digital era: Papers from the 40th Annual Conference of Computer Applications and Quantitative Methods in Archaeology (CAA), Southampton, 26-29 March 2012. Amsterdam University Press, Amsterdam, pp 307-312 Available at http:// arno.uva.nl/cgi/arno/show.cgi?fid=516092. Accessed on 10 May 2018

Green C, Gosden C, Cooper A, Franconi T, Ten Harkel L, Kamash Z, Lowerre A (2017) Understanding the spatial patterning of English archaeology: modelling mass data from England, 1500 BC to AD 1086. Archaeol J 174:244-280. https://doi.org/10.1080/00665983. 2016.1230436

Hanson JW (2011) The urban system of Roman Asia Minor and wider urban connectivity. In: Bowman AK, Wilson A (eds) Settlement, urbanization, and population. Oxford University Press, Oxford, pp 229-275. https://doi.org/10.1093/acprof:oso/9780199602353.003.0009

Hanson JW (2016) An urban geography of the Roman world, 100 BC to AD 300. Archaeopress, Oxford

Haynes IP (2000) Britian's first information revolution; the Roman army and the transformation of economic life. In: Erdkamp P (ed) The Roman army and the economy. Gieben, Amsterdam, pp 111-126

Herzog I (2014) Least-cost paths - some methodological issues. Internet Archaeol 36. https://doi. org/10.11141/ia.36.5

Jones MJ (2004) Cities and urban life. In: Todd M (ed) A companion to Roman Britain. Blackwell, Oxford, pp 162-192. https://doi.org/10.1002/9780470998861.ch10

Lambrick G, Robinson M, Dodd A (2009) The Thames through time: the archaeology of the gravel terraces of the upper and middle Thames: the Thames Valley in late prehistory, 1500 BC-AD 50. Oxford University School of Archaeology, Oxford

Macklin MG, Lewin J, Jones AF (2014) Anthropogenic alluvium: an evidence-based meta-analysis for the UK Holocene. Anthropocene 6:26-38. https://doi.org/10.1016/j.ancene.2014.03.003

Margary ID (1973) Roman roads in Britain, 3rd edn. J. Baker, London

Marzano A (2011) Rank-size analysis and the Roman cities of the Iberian Peninsula and Britain: some considerations. In: Bowman AK, Wilson A (eds) Settlement, urbanization, and population. Oxford University Press, Oxford, pp 196-228. https://doi.org/10.1093/acprof: oso/9780199602353.003.0008

Mattingly DJ (2006) An imperial possession: Britain in the Roman empire, 54 BC-AD 409. Allen Lane, London/New York

Morris FM (2010) North Sea and channel connectivity during the late Iron Age and Roman period (175/150 BC - AD 409). Archaeopress, Oxford

O'Sullivan D, Unwin D (2010) Geographic information analysis, 2nd edn. John Wiley \& Sons, Hoboken. https://doi.org/10.1002/9780470549094

Powell K, Smith A, Laws G, Allen L (2010) Evolution of a farming community in the upper Thames Valley: excavation of prehistoric, Roman and post-Roman landscape at Cotswold Community, Gloucestershire and Wiltshire. Oxford Archaeology, Oxford

Rippon S (2007) Focus or frontier? The significance of estuaries in the landscape of southern Britain. Landscape 8(1):23-38. https://doi.org/10.1179/lan.2007.8.1.23

Rippon S, Smart C, Pears B (2015) The fields of Britannia. Oxford University Press, Oxford.

Robinson MA, Lambrick GH (1984) Holocene alluviation and hydrology in the upper Thames basin. Nature 308(5962):809-814. https://doi.org/10.1038/308809a0 
Robinson MA (1992) Environment, archaeology, and alluvium on the river gravels of the South Midlands. In: Needham S, Macklin MG (eds) Archaeology under alluvium. Oxbow, Oxford, pp 197-208

Scheidel W (2007) Demography. In: Scheidel W, Morris I, Saller RP (eds) The Cambridge economic history of the Greco-Roman world. Cambridge University Press, Cambridge, pp 38-86. https://doi.org/10.1017/CHOL9780521780537.004

Salway P (1981) Roman Britain. Clarendon Press/Oxford University Press, Oxford/New York

Smith A, Allen M, Brindle T, Fulford M (2016) The rural settlement of Roman Britain: new visions of the countryside of Roman Britain. Society for the Promotion of Roman Studies, London

Van de Noort RV (2011) North Sea archaeologies: a maritime biography, 10,000 BC - AD 1500. Oxford University Press, Oxford

Wilson A (2011) City sizes and urbanization in the Roman Empire. In: Bowman AK, Wilson A (eds) Settlement, urbanization, and population. Oxford University Press, Oxford, pp 161-195. https://doi.org/10.1093/acprof:oso/9780199602353.003.0007

Open Access This chapter is licensed under the terms of the Creative Commons Attribution 4.0 International License (http://creativecommons.org/licenses/by/4.0/), which permits use, sharing, adaptation, distribution and reproduction in any medium or format, as long as you give appropriate credit to the original author(s) and the source, provide a link to the Creative Commons licence and indicate if changes were made.

The images or other third party material in this chapter are included in the chapter's Creative Commons licence, unless indicated otherwise in a credit line to the material. If material is not included in the chapter's Creative Commons licence and your intended use is not permitted by statutory regulation or exceeds the permitted use, you will need to obtain permission directly from the copyright holder. 